\title{
Currency substitution: new evidence from emerging economies
}

\author{
Faruk Selçuk* \\ Department of Economics, Bilkent University, Bilkent 06533, Ankara, Turkey
}

Received 4 October 2001; received in revised form 26 April 2002; accepted 11 July 2002

\begin{abstract}
This paper provides new empirical evidence for currency substitution in different emerging market economies. Estimation results from a money-in-the-utility-function framework indicate that foreign currencies are strong substitutes for domestic currency in producing liquidity services.
\end{abstract}

(C) 2002 Elsevier Science B.V. All rights reserved.

Keywords: Currency substitution; Emerging economies; Money-in-the-utility-function

JEL classification: C5; E4; F3

\section{Introduction}

Currency substitution is a widely observed phenomenon in both developing and developed countries. The significance of currency substitution plays an important role in financing government deficit, determining an appropriate foreign exchange regime, implementing a stabilization program and conducting the monetary policy. ${ }^{1}$ There are different approaches to model currency substitution in an economy. Carniero and Faria (1996) employ a Ramsey model for open economies by including both domestic and foreign currencies in the utility function. The model is in transaction cost framework including an indexed money. Their findings suggest that increasing inflation causes an increase in demand for indexed money and a decrease in demand for narrow money. They call this the 'substitution effect'. Agénor and Khan (1996) investigate currency substitution with a dynamic,

*Tel.: + 90-312-290-2074; fax: +90-312-266-5140.

E-mail address: faruk@bilkent.edu.tr (F. Selçuk).

${ }^{1}$ See Calvo and Végh (1992) and Giovannini and Turtelboom (1992) for an early survey of currency substitution literature. Ramirez-Rojas (1985), Sahay and Végh (1995), Savastano (1999), and Selçuk (1994, 1997, 2001) provide evidence for different countries and regions. See Uribe (1999) and Schmitt-Grohé and Uribe (2000) on stabilization policies and the costs of dollarization. 
forward-looking model. In this framework, allocation of currencies is pre-determined in a model of household behavior, and the actual currency holding is determined in a multi-period cost-ofadjustment process. Uribe (1997) employs a cash-in-advance model in which domestic currency is always in circulation. According to the cash-in-advance constraint, consumers must hold some amount of domestic currency to purchase goods. However, this cash-in-advance model differs from other conventional cash-in-advance models in the sense that the economy accumulates experience in using foreign currencies and the accumulated experience reduces the cost of using foreign currencies. This feature of the model explains a widely observed hysteresis effect, i.e. irreversibility of currency substitution. Sibert and Liu (1993) also model currency substitution in a cash-in-advance framework. In their model, there is a cost occurring due to exchange of currencies before trading. They attribute this cost to 'substitutability of currencies'. Berg and Borensztein (2000) analyze how dollarization affects the choice of an appropriate exchange rate regime, i.e. a fixed or a flexible exchange rate policy. Mourmouras and Russell (2000) give examples of misuse of tariffs and quotas, tax evasion and narcotics trafficking in order to explain the factors behind the progressive and increasing degree of currency substitution.

Imrohoroglu (1994) employs a money-in-the-utility-function model to estimate currency substitution between Canada and the Unites States. Selçuk (1997) applies the same model to estimate the degree of currency substitution in Turkey. Both studies assume that the preferences are additively separable in consumption and liquidity. However, several studies have shown that aggregate expenditure is a significant argument in money demand functions, especially in developing countries. See, for example, Arrau et al. (1995) and Reinhart and Végh (1995).

This paper provides new empirical evidence for currency substitution in different emerging market economies in the European Union periphery. Different currencies in these economies are modeled in a money-in-the-utility-function framework. It is assumed that the preferences are not additively separable in consumption and liquidity. The estimation results indicate that foreign currencies are a strong substitute for domestic currency in these economies.

\section{The model}

The economy consists of infinitely lived identical individuals. At the beginning of each period, a representative individual decides how much to consume, $c_{t}$, how much to save in the form of domestic and foreign real bonds, $b_{t}, b_{t}^{*}$, and how much to hold in the form of domestic real balances, $h=m / p$, and foreign real balances, $h^{*}=m^{*} / p^{*}$. In order to make this decision, the representative agent maximizes the expected discounted utility:

$$
E \sum_{t=0}^{\infty} \beta^{t} U\left(c_{t}, h_{t}, h_{t}^{*}\right)
$$

subject to budget constraint:

$$
c_{t}+b_{t}+b_{t}^{*}+h_{t}+h_{t}^{*} \leq y_{t}-\tau_{t}+\frac{h_{t-1}}{1+\pi_{t}}+\frac{h_{t-1}^{*}}{1+\pi_{t}^{*}}+\frac{1+i_{t-1}}{1+\pi_{t}} b_{t-1}+\frac{1+i_{t-1}^{*}}{1+\pi_{t}^{*}} b_{t-1}^{*}
$$

where $\beta$ is the subjective discount factor; $c_{t}$ per capita consumption, $b_{t}=B_{t} / P_{t}$ denotes the real value 
of holdings of domestic risk-free nominal bonds $\left(B_{t}\right) ; b_{t}^{*}=B_{t}^{*} / P_{t}^{*}$ denotes the real value of foreign risk-free nominal bonds; $i_{t}$ is the domestic nominal interest rate; $i_{t}^{*}$ is the foreign nominal interest rate; $\pi_{t}$ and $\pi_{t}^{*}$ are the domestic and foreign rates of inflation. Each individual receives an exogenous endowment $y_{t}$ and is subject to lump-sum tax $\tau_{t}$.

We assume that money enters the agent's utility function because it provides cost reducing service. It is assumed that the preferences are not additively separable in consumption and liquidity: ${ }^{2}$

$$
U\left(c_{t}, h_{t}, h_{t}^{*}\right)=\frac{c_{t}^{\gamma}}{\gamma} x\left(h_{t}, h_{t}^{*}\right)
$$

where $c_{t}$ is consumption and $x_{t}$ is money services. Money services are produced by both domestic and foreign real balances in a Constant Elasticity of Substitution production function:

$$
x_{t}=\left[\alpha h_{t}^{-\rho}+(1-\alpha) h_{t}^{*-\rho}\right]^{-1 / \rho}
$$

The assumed form of utility function in Eq. (3) results in Euler equations which imply the following estimation equations:

$$
\begin{aligned}
& 1-\beta\left(\frac{1+i_{t}^{*}}{1+\pi_{t+1}^{*}}\right)\left(\frac{c_{t+1}}{c_{t}}\right)^{\gamma-1}\left[\frac{\alpha h_{t+1}^{-\rho}+(1-\alpha) h_{t+1}^{*}}{\alpha h_{t}^{-\rho}+(1-\alpha) h_{t}^{*-\rho}}\right]^{-1 / \rho}=d_{1, t+1} \\
& \alpha \frac{c_{t}}{\gamma}\left[h_{t}^{-\rho}+(1-\alpha) h_{t}^{*-\rho}\right]^{-1} h_{t}^{-\rho-1}-\frac{i_{t}}{1+i_{t}}=d_{2, t+1} \\
& \left(\frac{\alpha}{1-\alpha}\right)\left(\frac{h_{t}^{*}}{h_{t}}\right)^{1+\rho}-\frac{i_{t}}{i_{t}^{*}}\left(\frac{1+i_{t}^{*}}{1+i_{t}}\right)=d_{3,+1}
\end{aligned}
$$

where the Euler equation errors are denoted as $d_{i, t+1}$. The Hansen (1982) GMM approach can be utilized to estimate the parameters of these equations. The instrument set consists of the variables in the estimation equation, lagged once.

\section{Data}

Since there is no reliable measure of foreign currency in circulation, empirical research on currency substitution uses foreign currency deposits as an approximation. We consider seven emerging markets on the periphery of the European Union: the Czech Republic, Hungary, Israel, Jordan, Poland, the Slovak Republic, and Turkey. ${ }^{3}$ For Hungary, Israel, Poland, and Jordan, the data for M2 and foreign currency deposits are taken directly from Datastream. For other countries, M2 data are calculated as

\footnotetext{
${ }^{2}$ Holman (1998) investigates a money-in-the-utility-function model under a variety of specifications of the representative agent's objective function.

${ }^{3}$ Data for the Czech Republic, Turkey, Jordan and the Slovak Republic are taken from International Financial Statistics (IFS). The rest of data are taken from Datastream. The sample periods are as follows: Czech Republic 1993:01-2000:12, Hungary 1991:01-2000:10, Israel 1993:1-2000:12, Jordan 1994:1-2000:1, Poland 1997:01-2001:03, the Slovak Republic 1993:01-2001:01 and Turkey 1987:01-1999:12.
} 
the sum of currency in circulation, demand deposits, time and saving deposits. The domestic prices are consumer price indices for all countries. Foreign price index is assumed to be the US consumer price index. The foreign nominal interest rate is assumed to be the US 10-year treasury bill rate. The yearly real consumption figures from the Economist Intelligence Unit database are converted to monthly data by interpolation.

\section{Estimation results}

The estimation results are obtained with a routine written in Winrats 32 . The program automatically calculates the optimal weighting matrix $W$ in a non-linear system estimation procedure. The initial values are $\alpha=0.5, \beta=1.0, \gamma=0.1$ and $\rho=-0.8$. Convergence is accepted when relative changes in the parameter vector are less than $10^{-3}$. The results are given in Table 1 . In this estimation, there are $3 \times 5=15$ orthogonality conditions and four parameters. The remaining eleven overidentifying restrictions are tested by the $J$-statistic. Calculated $J$-statistics (not reported) were large relative to the degrees of freedom which means that the overidentifying restrictions are rejected at very small significance levels.

According to the estimation results, foreign balances have a significant share in producing liquidity services. The highest share of foreign balances are in Turkey (53\%), Poland (50\%), the Czech Republic (42\%) and Israel (39\%). The discount factor $(\beta)$ estimates are all statistically significant and less than 1 for all countries. As expected, relatively high inflation economies such as Hungary, the

Table 1

GMM estimation results

\begin{tabular}{llcccc}
\hline & $\pi$ & $\alpha$ & $\beta$ & $\gamma$ & $\rho$ \\
\hline Czech Rep. & 0.60 & 0.58 & 0.95 & $0.006^{*}$ & -0.42 \\
& & $(0.05)$ & $(0.03)$ & $(0.003)$ & $(0.07)$ \\
Hungary & 1.45 & 0.85 & 0.76 & 0.33 & $0.06^{* *}$ \\
& & $(0.04$ & $(0.05)$ & $(0.08)$ & $(0.12)$ \\
Israel & 0.60 & 0.61 & 0.88 & $0.00^{*}$ & -0.44 \\
& & $(0.08)$ & $(0.01)$ & $(0.00)$ & $(0.02)$ \\
Jordan & 0.28 & 0.98 & 0.98 & 0.0001 & $0.47^{* *}$ \\
& & $(0.01)$ & $(0.01)$ & $(0.0000)$ & $(0.34)$ \\
Poland & 0.74 & 0.50 & 0.93 & $0.00^{* *}$ & -0.80 \\
& & $(0.13)$ & $(0.01)$ & $(0.00)$ & $(0.08)$ \\
Slovak Rep. & 0.75 & 0.97 & 0.79 & 0.76 & $-0.22^{*}$ \\
& & $(0.01)$ & $(0.01)$ & $(0.13)$ & $(0.09)$ \\
Turkey & 4.19 & 0.47 & 0.80 & 0.001 & -0.27 \\
& & $(0.03)$ & $(0.01)$ & $(0.0002)$ & $(0.05)$ \\
\hline
\end{tabular}

Average monthly inflation (in percent) denoted by $\pi$. The estimated parameter $\alpha$ indicates the share of domestic real balances in the production of money services. The estimated subjective discount factor is denoted by $\beta$. An estimate of the elasticity of substitution between domestic and foreign currencies can be obtained as $\epsilon_{m}=1 /(1+\rho)$. Asymptotic standard errors are in parenthesis. All coefficients (except six) are significant at less than $1 \%$ significance level. * Indicates that the coefficient is significant at $5 \%$ significance level. ** Indicate that the coefficient is not significant at conventional significance levels. 
Slovak Republic, and Turkey have relatively lower discount rates. This means that the residents of high inflation economies attribute relatively less importance to the future by discounting the future utility heavily.

The assumed form of the utility function in Eq. (3) implies that elasticity of marginal utility with respect to consumption equals to $\gamma-1$. The estimated $\gamma$ indicates that this elasticity is very close to (minus) one in the Czech Republic, Israel, Jordan, and Turkey. The same elasticity is less than one (in absolute value) in Hungary and the Slovak Republic. The parameter estimate is insignificant for Poland. The estimates of $\gamma$ also show that the elasticity of substitution between consumption at any two points in time $\left(\epsilon_{c}=1 /(1-\gamma)\right)$ is around one in most of the countries. Finally, the estimated $\rho$ parameters imply a positive elasticity of substitution between domestic and foreign real balances $\left(\epsilon_{m}=1 /(1+\rho)\right)$. Furthermore, the implied elasticity is greater than one: the Czech Republic: 1.72, Israel: 1.78, Poland: 5.0, the Slovak Republic: 1.28, and Turkey: 1.4. For Hungary and Jordan, the parameter estimate is insignificant. We conclude that the foreign currencies are strong substitutes for domestic currency in providing liquidity services in these economies.

\section{Acknowledgements}

The author would like to thank a referee of this journal whose comments improved the paper significantly.

\section{References}

Arrau, P., De Gregorio, J., Reinhart, C.M., Wickham, P., 1995. The demand for money in developing countries: assessing the role of financial innovation. Journal of Development Economics 46, 317-340.

Agénor, P., Khan, M.S., 1996. Foreign currency deposits and the demand for money in developing countries. Journal of Development Economics 50, 792-807.

Berg, A., Borensztein, P., 2000. The Choice of Exchange Rate Regime and Monetary Target in Highly Dollarized Economies. IMF Working Paper: WP/00/29.

Calvo, G.A., Végh, C., 1992. Currency substitution in developing countries: an introduction. Revista de Analisis Economico 7 (1), 3-28.

Giovannini, A., Turtelboom, B., 1992. Currency Substitution. NBER Working Paper No. 4232.

Hansen, L.P., 1982. Large sample properties of generalized method of moments estimators. Econometrica 50 (4), 1029-1054.

Holman, J.A., 1998. GMM estimation of a money-in-the-utility-function model: the implications of functional forms. Journal of Money, Credit, and Banking 30 (4), 679-698.

Imrohoroglu, S., 1994. GMM estimates of currency substitution between the Canadian and the US dollar. Journal Of Money, Credit, and Banking 26 (4), 792-807.

Mourmouras, A., Russell, S.H., 2000. Smuggling, Currency Substitution and Unofficial Dollarization: A Crime-Theoretic Approach. IMF Working Paper: WP/00/176.

Ramirez-Rojas, C.L., 1985. Currency substitution in Argentina, Mexico, Uruguay. International Monetary Fund Staff Papers 32 (4), 629-667.

Reinhart, C.M., Végh, C., 1995. Nominal interest rates, consumption booms and lack of credibility: a quantitative examination. Journal of Development Economics 46, 357-378.

Sahay, R., Végh, C., 1995. Dollarization in Transition Economies: Evidence and Policy Implications. IMF Working Paper: WP/95/96. 
Savastano, M., 1999. Dollarization in Latin America-Recent Evidence and Some Policy Issues. IMF Working Paper: WP/99/04.

Schmitt-Grohé, S., Uribe, M., 2000. Stabilization policy and the costs of dollarization. Journal of Money, Credit, and Banking 33, 482-509.

Selçuk, F., 1994. Currency substitution in Turkey. Applied Economics 26, 509-518.

Selçuk, F., 1997. GMM estimation of currency substitution in a high inflation economy: evidence from Turkey. Applied Economics Letters 4, 225-227.

Selçuk, F., 2001. Seigniorage, currency substitution, and inflation in Turkey, Russian and East European. Finance and Trade 37 (6), 41-50.

Sibert, A., Liu, L., 1993. Government Finance in a Model of Currency Substitution. IMF Working Paper: WP/93/80.

Uribe, M., 1997. Hysteresis in a simple model of currency substitution. Journal of Monetary Economics 40 (1), $185-202$.

Uribe, M., 1999. Comparing the welfare costs and initial dynamics of alternative inflation stabilization policies. Journal of Development Economics 59, 295-310. 